\title{
doispontos:
}

\section{O poético e o prosaico: o fim da lírica em Walter Benjamin}

\author{
Ulisses Razzante Vaccari \\ Doutor em Filosofia pela USP, atualmente professor no Departamento de Filosofia da UFSC. \\ ulisses_vaccari@hotmail.com
}

Resumo: O presente texto procura identificar alguns padrões da leitura benjaminiana de Baudelaire e Hölderlin. Em ambos os poetas, Benjamin ressalta um mesmo tema: a crise da poesia lírica em tempos modernos de industrialização. Baudelaire e Hölderlin, segundo Benjamin, procuram transpor a forma poética lírica em uma poesia prosaica, mais afeita ao homem moderno citadino e industrial, marcado pelo embotamento da percepção por meio do trabalho da consciência e da memória voluntária. Somente o recurso à poesia prosaica e alegórica é capaz de falar ao homem das grandes cidades. Num segundo momento, o texto procura trazer à tona alguns paralelos dessa interpretação com o teatro épico de Brecht. Aponta-se para a possibilidade de identificação do gênero da poesia prosaica com o gênero épico, no sentido de que este último visa igualmente a uma crítica da obra de arte como bela aparência. Palavras-chave: poesia lírica, poesia prosaica, crise da lírica, estética do choque, imaginação, memória.

\section{The poetic and the prosaic: the end of lyric in Walter Benjamin}

\begin{abstract}
The present text tries to identify some standards of the Benjaminian reading of Baudelaire and Hölderlin. In both poets, Benjamin stresses the same theme: the crisis of lyrical poetry in modern times of industrialization. Baudelaire and Hölderlin, according to Benjamin, seek to transpose the poetic lyric form into a prosaic poetry, more affectionate to modern urban and industrial man, marked by the blunting of perception through the work of consciousness and voluntary memory. Only the use of prosaic and allegorical poetry is able to speak to the man of the great cities. In a second moment, the text tries to bring to light some parallels of this interpretation with the epic theater of Brecht. One points to the possibility of identifying the genre of prosaic poetry with the epic genre, in the sense that the latter also aims at a critique of the work of art as a beautiful appearance.
\end{abstract}

Key-words: lyrical poetry, prosaic poetry, lyrical crisis, shock aesthetics, imagination, memory.

O presente texto se relaciona com o tema dos "fins da arte", ao realizar uma interpretação da questão do fim da poesia lírica em Walter Benjamin, no sentido não de finalidade, mas no de término. Seguindo a tradição de Hegel acerca do fim da arte na modernidade, Benjamin, ao ler poetas modernos, identifica o fim da forma lírica na poesia. Procurar-se-á identificar aqui, nas duas primeiras partes do texto, alguns padrões da leitura benjaminiana de dois poetas modernos em especial: Baudelaire e Hölderlin. Em ambas as interpretações, de ambos os poetas, Benjamin ressalta um mesmo tema: a crise da poesia lírica em tempos modernos de intensa industrialização. A partir desse diagnóstico, procurar-se-á mostrar de que modo ambos os poetas, na interpretação de Benjamin, procuram transpor a forma lírica em uma poesia prosaica, mais afeita ao homem moderno citado e industrial. Com a percepção embotada pelo trabalho da consciência e da memória voluntária no sentido de aparar os choques cotidianos provenientes do convívio com a técnica, a poesia 
lírica não encontra mais eco nesse homem moderno. $\mathrm{O}$ recurso à poesia prosaica, alegórica, tem assim o objetivo de falar ao coração desse homem submetido aos choques das grandes cidades e dos aparelhos técnicos que inundam seu cotidiano. Na terceira parte do texto, de caráter conclusivo, procurar-se-á trazer à tona ainda alguns paralelos dessa interpretação benjaminiana de Baudelaire e Hölderlin com a leitura que o autor das Passagens realiza do teatro épico de Brecht. Aponta-se aqui para a possibilidade de identificação do gênero da poesia prosaica com o gênero épico, no sentido de que este último, como aquela primeira, visa também a uma crítica da obra de arte como bela aparência ao manter sujeito e objeto afastados e tensionados entre si, ao contrário do que se observa no gênero lírico e no dramático.

\section{A interpretação de Baudelaire}

Benjamin inicia o ensaio Sobre alguns temas em Baudelaire mencionando a condição singular do poeta lírico no auge do capitalismo industrial do século XIX. Todo o ensaio é perpassado pela ideia de que os tempos são avessos à poesia lírica de um modo geral, algo notado pelo próprio Baudelaire em As Flores do Mal:

Baudelaire teve em mira leitores que se veem em dificuldades ante a leitura da poesia lírica. O poema introdutório de As Flores do mal se dirige a esses leitores. Com sua força de vontade e, consequentemente, seu poder de concentração, não se vai longe [...]. É surpreendente encontrar um poeta lírico que confie nesse público - de todos, o mais ingrato (Benjamin, 2000, p.103).

Nas sociedades marcadas por técnicas avançadas de reprodução e pela experiência das massas, não há lugar para a poesia lírica. A percepção humana, antes sensível à beleza, foi submetida nas grandes cidades a um intenso treinamento de choque, que terminou por embotá-la, tornando-a insensível ao lirismo. Esse processo de embotamento da sensibilidade do público desloca o poeta lírico para a periferia da cultura. Muitos motivos na produção de Baudelaire evocam a perda da centralidade e dos privilégios do poeta, em contraposição a seu papel central na antiguidade clássica. No conhecido poema Vinho dos Trapeiros, Baudelaire equipara o poeta ao catador de trapos; como este, ele procura suas rimas em meio aos detritos e dejetos da sociedade industrial, fazendo sua poesia do lixo. Benjamin comenta assim o poema:

\footnotetext{
Os poetas encontram o lixo da sociedade nas ruas e no próprio lixo o seu assunto heroico. [...] Trapeiro ou poeta - a escória diz respeito a ambos; solitários, ambos realizam seu negócio nas horas em que os burgueses se entregam ao sono (apud Benjamin, 2000, p.78-9) ${ }^{1}$.
}

Às margens da sociedade burguesa, o poeta lírico é um solitário, um desajeitado, associando-se à escória e aos excluídos. O soneto $O$ albatroz reforça tal imagem, ao comparar a falta de jeito do poeta lírico com a deste pássaro observado no convés do navio: "Antes tão belo, como é feio na desgraça/Esse viajante agora flácido e acanhado" (apud Benjamin, 2000, p.77). O poeta, nessas imagens, deixa de ser o dileto dos deuses e das musas. Longe de ser um filho pródigo, um gênio, o poeta de Baudelaire é mais humano do que nunca, tal como é cantado no poema A perda da auréola ${ }^{2}$, contido no ciclo do Spleen de Paris. Em meio aos encontrões da multidão, das carruagens e dos cruzamentos frenéticos, o poeta desajeitado deixa cair sua auréola na lama do meio fio:

\footnotetext{
Ainda há pouco, quando atravessava a avenida, apressadíssimo, e saltitava na lama em meio a esse caos movediço em que a morte chega a galope por todos os lados ao mesmo tempo, minha auréola, num movimento brusco, escorregou da minha cabeça para a lama da calçada (Baudelaire, 2009, p.215).
}

Em vez de pegá-la de volta, o poeta regozija-se de tê-la perdido e pode, agora, se misturar incógnito aos mortais, e com eles embriagar-se na taverna. Junto à escória, aos trapeiros, o poeta participa do grupo dos conspiradores que se reúnem em segredo para planejar a próxima ofensiva contra Napoleão III. Benjamin, aqui, associa claramente Baudelaire à figura do conspirador: "[...] Marx fala das tavernas onde o conspirador subalterno 
se sentia em casa. Os vapores que aí se precipitavam eram também familiares a Baudelaire" (Benjamin, 2000, p.15). Caído das alturas do Olimpo, desfalcado de sua auréola, o poeta lírico agora encontra-se do lado da raça de Caim, "o rude, o faminto, o invejoso, o selvagem Caim" (Dupont, apud Benjamin, 2000, p.21), filho adotivo de Satã, a quem o poeta toma por Deus e dedica sua obra: "Ó tu, o Anjo mais belo e o mais sábio Senhor,/ Deus que a sorte traiu e privou do louvor,/Tem piedade, Satã, desta longa miséria!” (Baudelaire, 1985, p.427). Afastado do divino e do sagrado, o poeta, semelhante a Caim, adota Satã como seu pai e o profano como o deus a ser louvado. Baudelaire trabalha assim com uma inversão dos valores antigos, divinizados e enaltecidos pelo classicismo, ecoando em pleno século XIX a Querela dos antigos e modernos ${ }^{3}$. A modernidade se constitui e se funda a partir dessa inversão. Enquanto, na antiguidade, o heroísmo possuía traços bem definidos e era associado ao poder e ao status quo, na modernidade os valores heroicos constituem máscaras assumidas por aqueles que resistem ao poder e ao status quo, dentre os quais figura o próprio Baudelaire:

Flâneur, apache, dândi e trapeiro, não passavam de papéis entre outros. Pois o herói moderno não é herói - apenas representa o papel do herói. A modernidade heroica se revela como uma tragédia onde o papel do herói está disponível (Benjamin, 2000, p.94, grifo meu).

Assim como o herói, na modernidade, não é herói, mas apenas representa seu papel, a linguagem poética já não é a mesma da antiguidade. Para descrever um mundo em que os heróis não são heróis, mas figuras marginalizadas tais como o flâneur, o apache, o dândi e o trapeiro, a poesia moderna deve abandonar o posto de linguagem elevada e acercar-se do mundo e da linguagem próprios dessas figuras; deve, em última análise, abandonar a forma lírica e elevada, e conquistar a forma oposta, mais de acordo com a banalidade do cotidiano, do corriqueiro, a forma prosaica e mais próxima do humano. Em outros termos, a poesia deve abandonar a forma da bela aparência, do Belo Ideal e absorver a linguagem do dia-a-dia das tavernas das grandes cidades, como na figura do poeta que deixa cair sua auréola no barro do meio fio:

Suas imagens [da poesia de Baudelaire] são originais pela vileza dos objetos de comparação. Espreita o processo
banal para aproximar o poético [...] As Flores do Mal é o primeiro livro a usar na lírica palavras não só de proveniência
prosaica, mas também urbana. Com isso, não evita expressões que, livres da pátina poética, saltam aos olhos pelo
brilho do seu cunho. Usa termos como quinquet (candeeiro), wagon, omnibus e não se atemoriza diante de um
bilan (balanço), réverbère (lampião), voirie (lixeira). Assim se substitui o vocabulário lírico no qual, de súbito e
sem nenhuma preparação, aparece uma alegoria (Idem, p.96-7, grifo meu).

A necessidade de reestruturação da linguagem poética vem em Baudelaire acompanhada de sua definição de modernidade como o oposto da antiguidade, o que o filia à Querela dos antigos e modernos. Enquanto, na antiguidade, o grandioso e heroico se apresentava nos feitos de Imperadores e semideuses (nas histórias de Roma, nos feitos de Brutus), na modernidade, pelo contrário, o feito heroico apresenta-se nos gestos dos que se opõem ao aparente heroísmo de um Napoleão III. Assim Blanqui, o conspirador, surge aos olhos modernos mais heroico que Napoleão ${ }^{4}$.É essa inversão operada pela modernidade que exige a superação da linguagem elevada e a conquista da forma prosaica, inversão que alcança seu ápice no elemento alegórico, típico da poesia de Baudelaire. "Esses ademanes linguísticos, típicos do artista em Baudelaire, só se tornam realmente significativos no alegórico" (Idem, p.96). O poema em prosa A perda da auréola mencionado acima exprime bem o sentido alegórico da poesia de Baudelaire. Para além da definição comum da alegoria como uma expressão imagética de uma ideia, em Benjamin seu significado vai muito além, tal como se pode ler em A Origem do Drama Trágico Alemão, obra em que trata de modo aprofundado deste conceito. Ao operar uma batalha contra o conceito classicista de símbolo, o qual, segundo Benjamin, possui um caráter absoluto e eterno, a alegoria surge como uma forma de reabilitação da temporalidade e da historicidade no interior da linguagem e da representação. Ao contrário do símbolo, que fecha em si todo sentido e o mantém intimamente unido ao significado, a alegoria traz em si uma abertura na qual se torna possível a representação do sentimento de transitoriedade do mundo: 
A palavra 'história' está gravada no rosto da natureza com os caracteres da transitoriedade. A fisionomia alegórica da história natural [...] está realmente presente sob a forma da ruína. [...] Assim configurada, a história não se revela como processo de uma vida eterna, mas antes como o progredir de um inevitável declínio. Com isso, a alegoria coloca-se declaradamente para lá da beleza (Benjamin, 2011, p.189).

Tal é o sentido proveniente dos dramas barrocos analisados por Benjamin na obra, nos quais o mundo regido por leis divinas é abalado pelas guerras religiosas próprias do século XVII. Por meio do caráter alegórico, próprio desses dramas, a história passa a ser vista não mais sob o ponto de vista do eternamente harmônico (como no símbolo classicista), mas a partir do viés do declínio e da decadência que permeia todas as coisas. Em última análise, a alegoria expressa o choque entre o desejo de eternidade e a consciência aguda de sua precariedade, que, segundo Benjamin, aparece também de forma pungente na poesia de Baudelaire. É possível afirmar que o caráter alegórico da poesia de Baudelaire é o mesmo dos dramas barrocos do século XVII. A alegoria presente em sua poesia tem como objetivo conduzir o leitor ao núcleo de sua concepção de arte em tempos modernos: apreender em suas imagens poéticas a vertiginosa passagem do tempo que a define. Tal é o sentido da conhecida afirmação do ensaio Sobre a modernidade segundo a qual "a Modernidade é o transitório, o efêmero, o contingente, é a metade da arte, sendo a outra metade o eterno e o imutável” (Baudelaire, 1996, p.26). Segundo essa afirmação, a arte contém em si ao mesmo tempo o eterno e o efêmero, num sentido muito próximo à afirmação de Benjamin segundo a qual "a alegoria se instala mais duravelmente onde o efêmero e o eterno coexistem mais intimamente” (Benjamin, 2011, p.247).

A consequência mais imediata dessa definição de alegoria que Benjamin identifica tanto nos dramas trágicos alemães do século XVII como em Baudelaire é a crítica da concepção de arte como bela aparência, própria do classicismo e do idealismo alemães. Como se lê na passagem citada acima de O Drama Trágico, “a alegoria coloca-se declaradamente para lá da beleza”. Ao afirmar que o alegórico insere na representação artística a "violência do real”, Benjamin encontra nesse elemento uma alternativa para definição corrente de arte como exposição sensível da Beleza (própria de Hegel). Tal concepção ganha força na definição segundo a qual a alegoria expõe a natureza da obra de arte como algo que não é dado de antemão, mas como um objeto construído pelo artista: "O poeta não pode esconder sua atividade combinatória, pois não é tanto o todo que ele visa em seus efeitos, com o fato de que esse todo foi por ele constituído, de modo plenamente visível” (apud Gatti, 2009, p.119). Como salienta Gatti (idem, p.120), tal concepção de Benjamin, se por um lado antecipa as teses da década de 30 da arte como destruição da bela aparência, remonta por outro à análise dos textos teóricos de Hölderlin realizados nos anos 10 e 20 em torno da sobriedade da arte. Tendo estabelecido isso, é preciso retornar à interpretação benjaminiana de Hölderlin dos anos 10 e 20 de modo a encontrar a fonte dessa concepção que marcará sua produção dos anos 30.

\section{A interpretação de Hölderlin}

O tema da marginalização do poeta lírico na modernidade, em oposição à sua centralidade na antiguidade clássica, surge como um dos principais objetos da poesia de Hölderlin. É conhecido, nesse sentido, o verso “para que poetas em tempos de indigência?”, da elegia Pão e vinho. Assim como em Baudelaire, a poesia de Hölderlin também gira em torno da poesia e da figura do poeta. Clamado por Heidegger como "o poeta dos poetas", Hölderlin poetiza em sua obra o destino do poeta moderno. Tal é o objeto de muitos de seus hinos, do romance Hipérion e da tragédia A morte de Empédocles. Em todos eles, grassa a concepção de que o moderno, imerso na abstração do pensamento e da filosofia, perdeu sua ligação originária com a natureza e com os celestiais. É a época da fuga dos deuses, cujo retorno cabe ao poeta cantar. O poeta, por isso, necessita de uma formação (Bildung) poética (Hipérion), de modo a tomar consciência de seu destino como educador da humanidade. No centro dessa formação está a concepção de que, para alcançar 
o povo e fazer da poesia novamente mitologia, o poeta moderno necessita apreender a diferença entre o antigo e o moderno; necessita apreender a essência do moderno para poder criar uma poesia com alcance novamente popular.

Do mesmo modo que Baudelaire se torna o centro das atenções de Benjamin a partir da década de 30, Hölderlin constitui uma figura central nos seus textos de juventude. Em 1915, escreve o ensaio Dois poemas de Friedrich Hölderlin, em que se põe a analisar a diferença formal de duas versões de um mesmo poema: Timidez (Blödigkeit) e Coragem de poeta (Dichtermut). Em ambos, apesar das alterações da segunda versão, o tema é o mesmo: a morte iminente da poesia e a tomada de consciência do poeta frente a esse seu destino. Segundo Benjamin: "Na primeira versão de seu poema, Hölderlin tem como objeto um destino: a morte do poeta. Essa morte é o centro a partir do qual deveria surgir o mundo do morrer poético. A existência naquele mundo seria a coragem do poeta" (Benjamin, 2013, p.24). Mas, apesar de expor o mesmo conteúdo - a morte do poeta e a coragem de enfrentá-la -, na segunda versão, o poema perde um pouco da ebriedade da primeira e adquire uma forma mais sóbria, que Benjamin só revela ao final do ensaio:

Ao longo deste estudo, evitamos propositalmente utilizar a palavra "sobriedade", com a qual estaríamos tentados a caracterizar o poema. Pois só agora deverão ser citadas as palavras de Hölderlin relativas ao elemento "sacro-sóbrio" [heilignüchtern], cujo sentido está agora definido (Idem, p.47).

A exigência de sobriedade da poesia moderna passou a ser um tema abordado teoricamente por Hölderlin a partir de 1800, período em que inicia seus trabalhos de tradução das tragédias de Sófocles para o alemão, em particular da Antígona. Numa carta a Casimir Böhlendorf de 4 de dezembro de 1801, Hölderlin explica a importância do tema ao amigo, antecipando algumas das principais questões das Observações sobre Édipo e Antígona, publicadas em 1804. Escreve, na carta: "Acredito que, para nós, a clareza da apresentação é, originariamente, tão natural como foi, para os gregos, o fogo do céu" (Hölderlin, 1994, p.132; tradução modificada). Enquanto o natural, para o grego, é o fogo do céu, o pathos sagrado, para o moderno o natural é a clareza e a sobriedade de exposição. A tarefa do poeta, nesse sentido, consiste em apreender e expor o propriamente nacional, o elemento natural do seu povo. Como essa apreensão e exposição é o mais difícil, devido ao impulso de formação (Bildungstrieb), a tendência do poeta grego foi buscar o oposto de sua natureza, a bela comoção na exposição. "Os gregos não são tanto mestres do pathos sagrado", escreve, pois este constitui o elemento inato do grego. No caso da modernidade, o nacional, o próprio, o inato é a sobriedade e a clareza de exposição. A tarefa do poeta moderno consiste assim em saber apreender essa clareza; saber, portanto, diminuir o elemento grego, o pathos sagrado, o fogo do céu, e trabalhar naquilo que lhe é natural. Em um poema igualmente conhecido, Metade da vida (Hälfte des Lebens), Hölderlin poetizou essa concepção, ao metaforizar o poeta moderno por meio da imagem do cisne ébrio de beijos: "Com peras douradas pende/E cheia de rosas bravas/A terra por sobre o lago,/Ó amados cisnes,/E ébrios de beijos/Mergulhais a cabeça/Na água sacro-sóbria [Ins heilignüchtern Wasser]” (Hölderlin, 1959, p.253; tradução modificada).

Ébrio de beijo, o cisne poeta mergulha a cabeça na água sacro-sóbria. No ensaio citado, Benjamin diferencia as duas versões do poema mencionado a partir dessa concepção do próprio Hölderlin, segundo a qual a poesia moderna deve ser sóbria na exposição, opondo-se, nesse sentido, à poesia grega, menos sóbria e mais ardente por natureza. A segunda versão do poema, Timidez, procura nesse sentido por uma exposição sóbria do sacro, diminuindo o elemento grego da poesia, o pathos, e ao mesmo tempo aumentando o elemento tipicamente moderno, a sobriedade 5 .

No ensaio $O$ conceito de crítica de arte no romantismo alemão, Benjamin retornaria novamente a Hölderlin, no mesmo sentido do ensaio de 1915. Dedicado ao estudo do conceito de crítica de arte do romantismo 
de Iena, em autores tais como os irmãos Schlegel e Novalis, Benjamin enxerga uma aproximação estreita dos autores românticos com Hölderlin:

\begin{abstract}
...a tese que funda sua relação filosófica [de Hölderlin] com os românticos é a proposição da sobriedade da arte. Esta proposição constitui o pensamento fundamental, em essência totalmente novo e ainda incalculavelmente ativo, da filosofia da arte romântica; a talvez maior época da filosofia ocidental da arte é marcada por ele (Benjamin, 1993, p.108).
\end{abstract}

A proposição da sobriedade da arte nos românticos aparece na relação da poesia com a reflexão, cujo modo de expressão supremo é o prosaico, "uma designação metafórica do sóbrio" (Idem, ibid.). Definida como uma atitude do pensamento e da consciência, a reflexão se opõe ao êxtase e à mania atribuída por Platão ao poeta no Fedro. Contra o poeta grego, considerado um mediador entusiasmado entre deuses e homens, o poeta romântico é reflexivo; produz sua poesia por meio da reflexão e do pensamento. A metáfora predileta dos românticos, por isso, é a da luz da consciência, que surge, por exemplo, nas primeiras linhas do poema Quíron, de Hölderlin, nos seguintes termos:

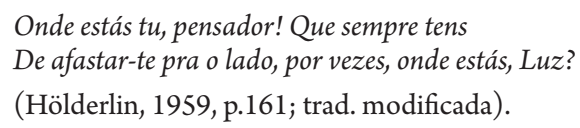

August Schlegel, por sua vez, proclama: "Clareza de consciência é a musa primeira do homem que aspira sua formação" (apud Benjamin, 1993, p.109). No caso dos românticos de Iena, essa luz da consciência e essa sobriedade da reflexão ganham expressão na forma prosaica do romance, na qual o êxtase, o furor poeticus, adquire a firmeza da terra do cotidiano. O prosaico, aqui, funciona como uma metáfora do sóbrio, como o modo próprio de exposição da natureza reflexiva do poeta moderno. Isso aponta para a concepção de que a forma mais apropriada de exposição da palavra poética, lembrando Baudelaire, não é mais a da lírica, mas a prosa romanesca, que também Hölderlin exerceu no Hipérion. Neste, a forma de exposição é fundamental. A síntese sacro-sóbria do moderno realizada nele incorpora ao mesmo tempo a linguagem filosófica, tão cara a Hölderlin. Ao longo do romance, muitas vezes o personagem homônimo vê-se enredado em reflexões filosóficas, próprias de um Fichte, acerca da origem da consciência ou da essência da modernidade. Para poder ser novamente compreendida e lida, a poesia moderna necessita deixar de lado a ardência do lirismo e valer-se da sobriedade da filosofia. Assim se explica, ao menos em parte, a incursão de Hölderlin - um poeta por excelência - no universo abstrato e conceitual da filosofia do fim do século XVIII: como uma tentativa de tornar a palavra poética mais clara e mais sóbria, mais de acordo com a natureza do homem moderno, menos sensível ao fogo do céu e ao pathos sagrado.

Em $O$ conceito de crítica de arte no romantismo alemão, Benjamin, ao mencionar Hölderlin, volta a utilizar o termo "sacro-sóbrio" para trazer à tona, na mesma discussão, o escrito mais representativo do poeta no que se refere à criação de uma poética tipicamente moderna: as Observações sobre Édipo e Antígona. Em particular, Benjamin cita o início das Observações sobre Édipo, em que Hölderlin compara a poesia moderna com a grega, e menciona a necessidade de uma poética moderna, baseada numa lei capaz de tornar calculável a produção poética:

À poesia moderna falta particularmente escola e ofício, isto é, que o seu modo de proceder possa ser calculado e ensinado e, quando for aprendido, possa ser repetido de modo confiante em sua execução. [...] Por isso, e sem mencionar motivos mais elevados, a poesia necessita particularmente de princípios e limites seguros e característicos. Um deles é precisamente aquele cálculo das leis (Hölderlin, SW II, p.849, tradução própria).

A poesia "sacro-sóbria", em última análise, é uma poesia que não depende unicamente do êxtase e do entusiasmo. Só é possível, nesse sentido, por meio do estabelecimento de uma lei poética calculável, que 
permita ensinar e transmitir de geração em geração o modo e a mecânica do fazer poético. O gênio poético, nessa acepção, não é apenas imaginação produtiva e autônoma, mas aquela força que se ancora ao mesmo tempo na reflexão e no entendimento ${ }^{6}$. A sobriedade do entendimento e da reflexão constitui a base a partir da qual é possível extrair a lei calculável da poesia e a estrutura lógica para toda e qualquer produção poética. Ao analisar a estrutura do Édipo e da Antígona de Sófocles, Hölderlin retira delas uma lei comum, que pode ser aplicada na poesia moderna: a cesura, também denominada "interrupção anti-rítmica". Situada em momentos distintos no Édipo e na Antígona, a cesura interrompe o fluxo dos acontecimentos, propiciando uma viragem no tempo que, a partir desse momento, se torna propriamente trágico. No caso do Édipo, o ponto de intersecção é situado na fala de Tirésias e, no caso de Antígona, na fala em que a heroína particulariza a lei de Zeus, ao proclamar "o meu Zeus". Situada em diferentes momentos no Édipo e na Antígona, a cesura permite dividir a tragédia em duas partes, de modo que a parte posterior se torna mais rápida do que a anterior. Trata-se de um corte operado na sequência das imagens, que descontinua a ação. Para designar a força desse corte, Hölderlin utiliza o termo hinreissen, rasgar ou arrancar, ato por meio do qual se conserva a consciência tanto do poeta como do espectador, mantendo separados o artístico e o real, a bela aparência e o próprio objeto representado.

O recurso da cesura, nesse caso, é um índice do uso da reflexão e do Juízo na produção poética. Por meio desse recurso, nos dizeres de Hölderlin, a tragédia enfatiza não o processo estético, aparente, da arte, mas faz ao mesmo tempo emergir a mecânica da criação poética. É isso o que Hölderlin quer dizer quando afirma que a cesura traz à tona a "representação mesma" e não apenas a alternância de representações poéticas. A cesura não visa à exposição do conteúdo da tragédia, mas acima de tudo dos mecanismos poéticos utilizados para construí-la. Hölderlin, em última análise, não está preocupado com o efeito estético do belo no público, mas em deixar em evidência o modo como esse belo é produzido. Importa mais ao espectador moderno, ao assistir à tragédia, estar consciente de que se trata de uma encenação de uma ação e não da ação propriamente dita. A tragédia moderna pensada por Hölderlin não permite, como no teatro dramático tradicional, o êxtase coletivo, envolvendo palco e plateia, obra e realidade. A interposição da cesura como um recurso da reflexão e da sobriedade poética deixa claro o limite entre a bela aparência e seu processo artístico de produção.

\section{O lado épico da verdade}

O interesse de Benjamin pela poesia sacro-sóbria de Hölderlin e pela poesia prosaica de Baudelaire pode ser explicado pelo mesmo motivo que lhe interessa o teatro épico de Brecht. A superação da lírica pura e o recurso ao prosaico, nos dois primeiros, podem ser encontrados também no teatro de Brecht. O termo "épico" atribuído a Brecht denota de saída uma diferenciação importante em relação aos gêneros lírico e dramático: trata-se do único gênero em que sujeito e objeto mantêm-se apartados entre si, sem se confundirem. No lírico, ocorre em geral uma diluição do mundo no eu, de modo que o mundo se torna expressão do mundo da subjetividade (como no expressionismo) ${ }^{8}$. No dramático, a diluição ocorre no sentido oposto, do eu no mundo, de modo que o mundo se emancipa do eu e se torna plenamente objetivo, como na exposição do destino da tragédia grega. No épico, eu e mundo permanecem tensionados e afastados entre si, cisão que, filosoficamente, constitui o fundamento de toda consciência. Não há no épico a possibilidade de fusão entre eu e mundo, o que faz da sobriedade sua marca característica, oriunda da relação com a reflexão e o pensamento, e expressa na forma prosaica e narrativa. Enquanto o gênero lírico carrega na musicalidade e no ritmo, o épico privilegia o discurso racional, prosaico, marca da figura do narrador 9 .

Próprio do gênero épico, o narrador está ligado à tradição oral, da qual depende uma memória privilegiada para contar histórias e feitos do passado. Transmite, assim, uma experiência épica a uma plateia de 
ouvintes atentos. Contrariamente ao poeta lírico, que canta somente para si um sentimento que ocorre no presente, o narrador épico conta para os outros uma história que ocorreu em outros tempos. Tal fato permite-o distanciar-se do objeto narrado, ao mesmo tempo em que o impede de se metamorfosear nos personagens cantados, como sói vem a ocorrer no drama tradicional, de origem aristotélica. Mais platônico que aristotélico, o gênero épico é o que mais se aproxima da sobriedade própria da filosofia socrática, cujos diálogos iniciam igualmente com uma referência a uma história ocorrida no passado ${ }^{10}$. No drama trágico, a ação transcorre no presente, eliminando a relação de distância com o ocorrido. No épico, a distância e a separação mantêm acesa a luz da consciência na produção artística, motivo pelo qual os teóricos do teatro épico geralmente se opõem tão radicalmente ao teatro catártico aristotélico, cujo princípio supremo (a catarse) não permite a convivência pacífica com a reflexão e a consciência de si. Nesse sentido, antes de Brecht, Hölderlin e Baudelaire já haviam procurado fazer arte privilegiando isso que Benjamin denomina o "lado épico da verdade".

O que permite unificar Hölderlin, Baudelaire e Brecht em torno do mesmo ideal, assim, é a aplicação da técnica da interrupção do fluxo poético como forma de conservação da consciência na produção da arte. No caso de Baudelaire, Benjamin chama a atenção para o fato de que sua composição poética incorporou o princípio do choque, imitando e poetizando os encontrões das multidões da metrópole. O próprio Baudelaire equipara, nos seguintes versos de As Flores do Mal, seu modo de criação poética à figura do esgrimista:

\footnotetext{
Ao longo dos subúrbios, onde nos pardieiros

Persianas acobertam beijos sorrateiros,

Quando o impiedoso sol arroja seus punhais

Sobre a cidade e o campo, os tetos e os trigais,

Exercerei a sós a minha estranha esgrima,

Buscando em cada canto os acasos da rima,

Tropeçando em palavras como nas calçadas,

Topando imagens desde há muito já sonhadas

(apud Benjamin, 2008, p.112).
}

Em seu comentário do poema, Benjamin escreve: "A experiência do choque é uma das que se tornaram determinantes para a estrutura de Baudelaire” (Id., ibid.). O choque, não apenas como conteúdo, mas incorporado à forma de sua poesia, provoca intermitências entre a imagem e a ideia, a palavra e o objeto, de modo que os opostos não se misturam jamais, permanecendo antes tensionados e afastados um do outro. Nas Flores do Mal, entretanto, o elemento lírico aparece ainda de forma nítida, ressoando nas rimas e na musicalidade própria daqueles versos, enquanto que, em O Spleen de Paris, o lírico é empurrado para segundo plano. Nestes poemas em prosa, observa-se o surgimento intenso e virulento do épico no seio da própria lírica, por meio da eliminação da rima e do ritmo, e da transfiguração do lírico no prosaico. Na abertura de seu livro, em carta a Arsène Houssaye, escreve Baudelaire:

Quem dentre nós não sonhou, nos seus dias de ambição, com o milagre de uma prosa poética, musical sem rima nem ritmo, flexível e desencontrada o bastante para se adaptar aos movimentos líricos da alma, às ondulações do devaneio, aos sobressaltos da consciência? (Baudelaire, 2009, p.29-31)

A transposição da lírica em prosa, a criação de uma prosa lírica, por mais paradoxal que seja, remete ao ideal sacro-sóbrio de Hölderlin, alcançado pelo princípio da interrupção, da intermitência na série das representações poéticas. Tal interrupção, ao impedir a fusão absoluta entre sujeito e objeto, abre espaço para momentos de reflexão tanto por parte do criador como do leitor e do espectador, que assim se separa do que está sendo contado ou representado no palco. No caso de Brecht, as interrupções ou estranhamentos são inseridos na cena por inúmeros elementos: a ironia sórdida, a paródia irreverente, os cartazes violentos, os figurinos toscos, a canção rude, os epílogos deslocados, e o gesto. Como afirma Benjamin: “... para o teatro 
épico a interrupção da ação está no primeiro plano. Nela reside a função formal das canções brechtianas, com seus estribilhos rudes e dilacerantes" (Benjamin, 2008, p.80). Com os recursos de interrupção do fluxo natural do êxtase dramático, Brecht procura desentranhar a parafernália técnica, a aparelhagem utilizada para a produção do espetáculo, deixando-a à vista, como os andaimes de uma obra. Lembrando o que dizia Hölderlin sobre a tragédia moderna, o que interessa nesse tipo de teatro é a exposição da mecânica por trás da produção do belo do que o efeito do belo propriamente dito. "O teatro épico", escreve Benjamin, "conserva do fato de ser teatro uma consciência incessante, viva e produtiva" (idem, p.81). A consciência de ser teatro e não a própria vida, como no teatro naturalista, provém do assombro que o teatro épico causa no espectador. "Com este assombro, o teatro épico presta homenagem, de forma dura e pura, a uma prática socrática” (ibid.), a prática do exercício do raciocínio e da razão. Curiosamente, também Hölderlin nutria apreço especial por Sócrates e Platão, pela capacidade única na história do pensamento de conjugar de modo intermitente e descontínuo imagem e palavra, conceito e metáfora, poesia e prosa.

\section{NOTAS}

1. Gagnebin (2012, p.33) mostra como a atividade do trapeiro, comparada por Baudelaire com a do chiffonnier ou do Lumpensammler, pode "também ser uma metáfora do trabalho do historiador materialista", cuja função, semelhante à do psicanalista, consiste em observar os restos, os detritos, enfim, tudo aquilo que é ignorado e descartado pela atividade consciente do historiador, permitindo-o, por um trabalho de reconstituição dos rastros deixados não intencionalmente pelas civilizações, desenterrar uma outra história e, portanto, constituir um outro futuro.

2. Sobre a importância desse poema na produção de Baudelaire, segundo a interpretação de Benjamin, cf. Wohlfarth, 1970.

3. Sobre a inserção de Baudelaire na tradição da Querela entre os antigos e modernos, cf. Habermas, 2000, p.13-18. Para o autor, Baudelaire se insere na tradição que remonta ao século XVII ao procurar pensar as características próprias do moderno em oposição aos antigos, de uma forma inteiramente nova. "Baudelaire parte do resultado da célebre querela dos antigos e modernos, mas desloca, de maneira característica, o peso do belo absoluto e do belo relativo" (p.15), escreve. Em curtas palavras, a obra de arte autêntica, nas palavras de Baudelaire, radicaliza sua efemeridade, e assim consegue "deter o fluxo constante das trivialidades, romper a normalidade e satisfazer o anseio imortal de beleza durante o momento de uma ligação fugaz do eterno com o atual" (p.15-6). Essa ligação do autêntico com o efêmero, que Baudelaire chama de a "dupla dimensão" do Belo (Baudelaire, 1996, p.10), Benjamin chamará de "imagem dialética".

4. "Ocasionalmente, Baudelaire quis também reconhecer a imagem do herói moderno no conspirador. 'Basta de tragédias!' - escreveu durante as jornadas de fevereiro em La salut public. 'Basta de histórias de Roma! Não seremos hoje maiores do que Brutus?'. Ser maior que Brutus significava naturalmente ser ainda menor. Pois quando Napoleão III chegou ao poder, Baudelaire nele não reconheceu o César. Nisto Blanqui lhe foi superior" (Benjamin, 2000, p.98).

5. Em sua tradução de Sófocles para o alemão, Hölderlin observa essa mesma lei poética, vertendo os nomes mitológicos em conceitos prosaicos, mais de acordo com a natureza do moderno. Assim, por exemplo, na tradução da Antígona: Zeus é traduzido por "pai da terra" ou "pai do tempo"; Hades, por "inferno", "mundo dos mortos", "lugar dos mortos" e "deus do inferno"; Eros, por "espírito do amor" e "espírito da paz"; Afrodite, por "beleza divina"; Ares, por "espírito de batalha"; Baco, por "deus da alegria"; Olimpo, por "céu"; deuses, por "espíritos" e assim por diante (cf. SW II, p. 1329-30). Em todos esses casos, trata-se de aproximar imagens que só fazem sentido ao grego, como Zeus e Hades, à natureza racional e prosaica dos modernos, que necessita sempre do conceito para se reportar à natureza. Incompreendidas por seus contemporâneos, as traduções de Sófocles feita por Hölderlin são comentadas por Benjamin em A tarefa do tradutor, de 1921, em que escreve: "Nelas, a harmonia das línguas é tão profunda que o sentido só é tocado pela língua como uma harpa eólia pelo vento” (2013, p.118). 
6. O modelo de Hölderlin, aqui, é Kant, que, na Crítica do Juízo, descreveu com clareza o ideal do gênio poético: "O gosto é, assim como a faculdade do juízo em geral, a disciplina (ou educação) do gênio; corta-lhe muito as asas e torna-o morejado e polido; ao mesmo tempo, porém, dá-lhe uma direção sobre o que e até onde ele deve estender-se para permanecer conforme a fins; e na medida em que ele introduz clareza e ordem na profusão de pensamentos, torna as ideias consistentes, capazes de uma aprovação duradoura e ao mesmo tempo universal, da sucessão de outros e de uma cultura sempre crescente" (Kant, 1998, p.226; B 203).

7. Para uma análise mais completa da interpretação benjaminiana da cesura de Hölderlin, cf. Gatti, 2009, p.39-41 e p.73-81 e Menke, 2005, p.112 e ss.

8. Como escreve Adorno: "Primariamente como expressão de um novo ânimo apreendido na cultura, por um lado, e como resultado de um constante desenraizamento dos compromissos de estilo, por outro, ao mesmo tempo criação e reação, o Expressionismo põe o Eu absoluto e exige o grito puro" (Expressionismus und künstlerische Wahrhaftigkeit. In: Adorno, 2015, p.609).

9. Para um estudo mais aprofundado acerca das diferenças entre os gêneros, cf. Rosenfeld, 2011, p.15-38 e 2012, p.27-36.

10. Os diálogos platônicos, ao iniciarem quase sempre com um personagem narrando a história que declara ter ouvido de outrem, que, por sua vez, a ouviu sendo narrada por outrem, e assim por diante, embora tenham sido escritos, atestam a proximidade com a tradição oral, tal como descreve Benjamin, por exemplo, em O Narrador: "A experiência que passa de pessoa a pessoa é a fonte a que recorreram todos os narradores. E, entre as narrativas escritas, as melhores são as que menos se distinguem das histórias orais contadas pelos inúmeros narradores anônimos” (2008, p.198).

\section{REFERÊNCIAS}

ADORNO, T. W. Noten zur Literatur. Frankfurt am Main: Suhrkamp, 2015.

BAUDELAIRE, C. As flores do mal. Trad. Ivan Junqueira. Rio de Janeiro: Editora Nova Fronteira, 1985.

Hedra, 2009.

. Pequenos poemas em prosa. [O Spleen de Paris]. Tradução Dorothée de Bruchard. São Paulo: . Sobre a modernidade. Tradução Suely Cassal. Rio de Janeiro: Paz e Terra, 1996.

BENJAMIN, W. O Conceito de Crítica de Arte no Romantismo Alemão. Trad. Márcio Seligmann-Silva. São Paulo: Iluminuras, 1993.

. Ensaios sobre Brecht. Trad. Claudia Abeling. São Paulo: Boitempo, 2017.

34,2013

. Escritos sobre mito e linguagem. Trad. Susana Kampff Lages e Ernani Chaves. São Paulo: Editora

. Obras Escolhidas. Trad. Sergio Paulo Rouanet. São Paulo: Editora Brasiliense, 2008.

. Origem do drama trágico alemão. Trad. João Barrento. Belo Horizonte, São Paulo: Editora Autêntica, 2011.

. Passagens. Trad. Irene Aron, Cleonice Paes Barreto Mourão. Belo Horizonte: Editora UFMG, São Paulo: Imprensa Oficial do Estado de São Paulo, 2007. 
GAGNEBIN, J., M. A pagar os rastros, recolher os restos. In: Sedlmayer, S.; Ginzburg, J. (org.) Walter Benjamin: Rastro, aura e história. Belo Horizonte: Editora UFMG, 2012.

HABERMAS, J. O Discurso Filosófico da Modernidade. Trad. Luiz Repa e Rodnei Nascimento. São Paulo: Martins Fontes, 2000.

HÖLDERLIN, F. Poemas. Tradução Paulo Quintela. Lisboa: Atlântida, 1959.

. Reflexões. Tradução de Márcia C. de Sá Cavalcante e António Abranches. Rio de Janeiro: Relume Dumará, 1994. Verlag, 1992.

. Sämtliche Werke und Briefe. Hg. von Jochen Schmidt. Frankfurt am Main: Deutscher Klassiker

KANT, I. Crítica da Faculdade do Juízo. Trad. António Marques e Valério Rohden. Lisboa: Imprensa Nacional - Casa da Moeda, 1998.

ROSENFELD, A. Brecht e o teatro épico. São Paulo: Perspectiva, 2012.

. O teatro épico. São Paulo: Perspectiva, 2011.

WOHLFARTH, I. "Perted'auréole": The Emergence of the Dandy. In: Modern Language Notes. Baltimore: May, 1970. 